\title{
Designing a Risk-Based Review Plan for Accrual Based Local Government Financial Reports
}

\author{
Fira Chairunnisa ${ }^{1 *}$ and Bambang Pamungkas ${ }^{2}$ \\ ${ }^{1,2}$ Universitas Indonesia, Depok, Indonesia
}

\begin{abstract}
The application of Accrual-Based Government Accounting Standards (SAP) since 2015 still causes problems including misstatement in Local Government Financial Reports (LKPD). The role of the Inspectorate in minimizing these problems is manifested in conducting a review of LKPD. Preliminary research shows that the implementation of LKPD review in Bandung District has not been effective in detecting financial statement misstatements. This study aims to evaluate and design a risk-based review plan on accrual-based LKPD at the Bandung District Inspectorate, and also expected to be a guideline for Regional Government Inspectorates in planning LKPD reviews to generate government financial reports in accordance with SAP. This study uses a case study approach with qualitative methods. The results of the study show that the LKPD review planning at the Bandung District Inspectorate has been carried out according to regulations and IIA standards, but there are weaknesses at the stage of entity's understanding and risk identification. The design of review procedures that have not implemented a risk-based approach also has an impact on an ineffective review, therefore in this study a risk-based LKPD review plan was designed. The output of this review plan will contain testing procedures in accordance with the risk areas of the financial statements.
\end{abstract}

Keywords: Government Financial Reports, Internal Audit; Review, Risk-Based.

\section{Introduction}

Since 2015 financial reporting in the public sector in Indonesia has experienced a transformation through the implementation of Government Regulation (PP) Number 71 of 2010 concerning Accrual-Based Government Accounting Standards (SAP) for all government entities, both central and regional. Accrual-based financial reporting to the government is useful for assessing accountability, evaluating government performance in cost efficiency, and presenting overall financial position so that it can be used for decision making (International Federation of Accountants, 2011). The accrual-based SAP application to the government not only provides benefits but also raises problems, especially in local governments. The main problem in the accrualbased SAP implementation includes accrual accounting data that is not fully disclosed and incorrectly presented, especially on asset accounts (Efendi, Dewi, \& Gamayuni, 2018).

To minimize the occurrence of problems in the application of accrual-based SAP, especially misstatement in the LKPD, each local government through the Inspectorate as an internal audit reviews the LKPD before being submitted to the Supreme Audit Agency (BPK). The Minister of Home Affairs Regulation (Permendagri) Number 4 of 2008 concerning Implementation Guidelines for the Review of LKPD explains that the purpose of the review is to provide limited confidence that the LKPD has been prepared through an adequate Internal Control System (SPI) and is presented in accordance with SAP. Based on these objectives, the role of the Inspectorate is significant in realizing quality LKPD and in accordance with accrual-based SAP. This is also in line with the results of the study (Maulana, Djamhuri, \& Purwanti, 2017) which concluded that quality review had an effect on the quality of the LKPD.

Preliminary research on Bandung District LKPD (Unaudited and Audited) shows that the LKPD review by the Inspectorate is not fully optimal in improving the quality of accrual LKPD presentation, which is indicated by the number of misstatements

* Corresponding author. Email address : fira.chairunnisa@gmail.com 
found by the BPK in the 2016 and LKPD 2017 audits, especially in Operational Reports (LO) which is a new component on accrual-based LKPD. Misrepresentation shows that unaudited LKPD presented by the Bandung District Government has not fulfilled the reliable characteristics mentioned in SAP, namely providing information that is free of misleading ideas and material errors, presenting truth honestly, and can be verified. This information could have an impact on decision making errors by users of financial statements.

The results of the LKPD review by the Inspectorate are expected to provide limited trust in the reliability of financial statements and provide preliminary information for external auditors about possible misstatements in financial statements. This goal can be achieved if the LKPD review is carried out with adequate procedures, in line with the results of research by (Bekaiang, Sondakh, \& Kalalo, 2017) and (Widyarini, Made, \& Ratnadi, 2016) which found that the review procedure had a significant effect on the quality of LKPD reviews. The review procedures contained in the review work program are prepared at the planning stage so it is important to evaluate. The approach used in designing audit procedures is to be able to focus time and resources effectively and efficiently on potential areas, namely through risk-based audits (Fraser, 2011). In addition (Sarens, Abdolmohammadi, \& Lenz, 2012) also stated in his research that there is a positive and significant relationship between the functions of internal audit and the use of risk-based audit plans.

Regulators have not provided standards and guidelines for local governments in applying accrual-based LKPD reviews, so the results of this study are expected to contribute insight into its application, especially in planning and preparing risk-based review procedures. In addition, this study can also enrich the literature related to financial report review planning in local governments. Research related to the implementation of LKPD reviews by the Inspectorate has been carried out including by (Alhakim, 2015) and (Sumanjaya, 2015), but both studies have not identified problems related to accrual-based review of LKPD, and provide real solutions to problems that occur in accrual-based LKPD implementation.

Based on the problems described, this study aims to evaluate and provide solutions to accrual-based LKPD review planning using a risk-based audit approach. This study answers the question: (a) How is the implementation of accrual-based LKPD review plans carried out by the Bandung District Inspectorate?; and (b) How is the accrualbased LKPD review planning design for the Bandung District Inspectorate?

\section{Literature Study}

\section{Transaction Cost Economy Theory}

Transaction Cost Economy (TCE) is a variation of agency theory, and is very suitable for internal audits (Spraakman, 1997). Internal audit provides information that is more useful for cost savings to managers than financial accounting information provided by external audits to owners and creditors, because internal audits can pursue operational information and not just financial accounting information (Williamson, 1985). Research carried out related to the relationship between TCE and internal audit empirically proved that the operational findings of internal auditing have uses for cost savings in the framework of TCE, and TCE can be applied to government organizations (Spraakman, 1997).

The results of research on TCE and internal audit further strengthen the internal audit function of the organization by providing added value in obtaining important information related to organizational cost saving practices, which in turn will have an impact on achieving organizational goals more efficiently.

\section{Audit Internal}

The Institute of Internal Auditors (IIA) defines internal audits as independent activities, objective beliefs, and consultations designed to improve the value and operations of organizations (IIA, 2016). According to IIA, Internal audits can support organizations in achieving goals through a structured and disciplined approach. The 
internal audit approach is carried out by evaluating and increasing the effectiveness of risk management, control and governance processes.

\section{Review of Government Financial Reports}

One of the roles of Internal Audit in organizations is to provide an assurance through review activities. Review of historical financial statements is an assignment to obtain limited assurance and shows conclusions designed to increase the level of trust of the users concerned with the presentation of financial statements. entity and its suitability with the financial reporting framework (IAASB, 2016). The IAASB definition in line with the Minister of Finance Regulation (PMK) Number 8/ PMK.09 /2015 concerning the Review Standards of the Regional Government Financial Statements stating that a review of the LKPD is a review of the accounting and presentation of LKPD by the Inspectorate to provide limited confidence that accounting has been carried out based on the Government Accounting System Regions, and LKPDs have been presented in accordance with Government Accounting Standards in an effort to assist Regional Heads to produce quality LKPDs.

Previous research related to the implementation of a review by the Inspectorate carried out by (Bekaiang et al., 2017) and (Widyarini et al., 2016) showed that the review procedure had a significant effect on the quality of local government financial report review. Subsequent research by (Maulana et al., 2017) proves that the quality of the LKPD review influences the quality of financial statements and is influenced by competencies, organizational commitment, and the entity's internal control system.

\section{Risk Management}

Along with the development of the internal audit function, there is a shift in the focus of activities from internal control to broader, namely providing guarantees to management and the board for the effectiveness of risk management. Risk management according to (Pickett, 2010) is a dynamic process to take steps in finding and handling risks that have an impact on goals. COSO defines Enterprise Risk Management as a process that is influenced by personnel, management and the board of directors of an entity, applied to strategy setting and designed to identify potential events that might affect the entity, and manage risk so that it is at the desired level to provide adequate confidence in the achievement of the entity's objectives (COSO, 2004).

According to (Moeller, 2009) effective risk management requires steps that must be implemented at all levels of the company and followed by different people, namely (1) risk identification, (2) risk assessment (quantitative and qualitative), (3) priority risk and response plan, and (4) risk monitoring.

\section{Risk based Internal Audit (RBIA)}

RBIA is defined as a methodology that links internal audit to the overall organizational risk management framework (IIA, 2014). RBIA allows internal audits to provide assurance to the board that the risk management process is effective in managing risk, in relation to risk appetite. RBIA starts with all organizational goals and provides opinions on whether risks that threaten these objectives can be reduced to levels acceptable to internal control, and that organizational goals will be achieved. According to (Moeller, 2011) the use of RBIA is important in maximizing and streamlining the internal audit function which is limited in time and resources, so that the internal audit function can focus on allocating their time and attention to the riskier areas of the organization. RBIA implementation is explained by (IIA, 2014) in three stages, as follows: (1) Assessment of risk maturity levels, (2) Periodic audit planning, and (3) Individual audit assignments.

Previous research related to RBIA was conducted by (Sarens et al., 2012) who found that the internal audit function has an important role in the implementation of corporate governance, which is significantly related to the use of risk-based audit plans, quality assurance and development programs, and audit committee input towards audit planning. (Coetzee \& Lubbe, 2014) in his research revealed that with the use of a riskbased audit model that is correct, more weaknesses than conventional audits would be found, thus increasing the effectiveness and efficiency of audit assignments. Other 
research by (Ayagre, 2014) related to RBIA practices in companies in developing countries shows that internal audit planning is developed based on input from the risk assessment process.

\section{Assignment Planning}

The 2200 International Internal Audit Standard states that internal auditors must prepare and document plans for each assignment that includes the assignment objectives, scope, time, and allocation of resources, and consider strategies, risk objectives that are relevant to the assignment (IIA, 2017). Stages that need to be done in planning assignments according to (IIA, 2017) include understanding of the entity (including identification and risk assessment), determining objectives, criteria, and scope of assignments, allocating assignment resources, and preparing assignment work programs. Based on the International Standards for Internal Audit 2240 it is stated that internal auditors must prepare and document work programs to achieve the objectives of the assignment, and in the work program include procedures for identifying, analyzing, evaluating, and documenting information during assignments (IIA, 2017).

\section{Research Method \\ Research design}

This study uses a case study approach, by presenting a complete picture of a phenomenon in its context (Yin, 2003). The method used in research is a qualitative method, an approach used to explore and understand the problems of both individuals and social groups (Creswell, 2014). The qualitative methods used in this study was through semi-structured interviews, document analysis, and surveys in the open-ended questionnaire. The three instruments used in this study are used simultaneously on different samples so that the results can complement each other.

\section{Data Collection}

This study uses primary and secondary data. Primary data used by the author was obtained directly from the Inspectorate of Bandung District, including internal documents related to accrual-based LKPD review planning (work program review of LKPD in 2017 and 2018, report on results of review of LKPD in 2017 and 2018, Unaudited LKPD and Audited in Bandung District 2017 and 2018), as well as the results of semi-structured interviews and questionnaires. While secondary data used include policies and regulations issued related to accrual-based LKPD review planning.

\section{Data Analysis}

Research instruments used in this study were semi-structured interviews, openended questionnaires, and document analysis. Data analysis in this study used descriptive analysis to describe and compare data obtained during the study, and content analysis to conclude the results of questionnaires and interviews. The data collected in the form of documents, interviews and questionnaires were analyzed so that they can be compared with their suitability with the internal audit framework, and are used to identify and assess risk as material in designing risk-based review programs.

\section{Result}

This section aims to summarize the results of analysis of several research instruments namely semi-structured interviews, document analysis, and open-ended questionnaire. The research results of the various instruments used are explained as follows:

\section{Interviews}

The interview in this study was conducted on the Leader of the 2018 LKPD Review Team at the Inspectorate as the executor of the review, and the Head of Accounting for the Regional Assets and Finance Agency (BAKD) as the person in charge of preparing the LKPD. The results of the interviews are summarized in table 1 as follows: 
Table 1 Interview Result

\begin{tabular}{|c|c|c|}
\hline Resource & $\begin{array}{c}\text { Purpose of } \\
\text { interview }\end{array}$ & Interview Result \\
\hline $\begin{array}{l}\text { Leader of the review } \\
\text { team }\end{array}$ & $\begin{array}{l}\text { Understand the } \\
\text { planning } \\
\text { implementation of the } \\
\text { LKPD review in } \\
\text { Bandung District and } \\
\text { its problems. }\end{array}$ & $\begin{array}{l}\text { - Review planning is carried out with reference to } \\
\text { Permendagri Number } 4 \text { of } 2008 \text {, and has not been } \\
\text { risk-based. } \\
\text { - The suitability analysis of the implementation of the } \\
\text { review plan with IIA standards shows that the } \\
\text { Inspectorate has carried out stages in the IIA } \\
\text { standard, but there are weaknesses including the } \\
\text { Inspectorate has not made adequate understanding } \\
\text { of the application system and business processes in } \\
\text { the area reviewed. In addition, risk identification is } \\
\text { based on discussions with the accounting head and } \\
\text { review of the previous year's inspection report, but } \\
\text { it is not carried out in a structured manner and } \\
\text { documented on a working paper, so the results are } \\
\text { not followed up with risk assessment and are not } \\
\text { used as material for the preparation of review } \\
\text { programs. Inspectorate also has not set a review } \\
\text { target that describes the results of risk assessments } \\
\text { based on the level of significance and likelihood of } \\
\text { occurrence. }\end{array}$ \\
\hline Head of Accounting & $\begin{array}{l}\text { - Knowing } \\
\text { business processes in } \\
\text { the preparation of the } \\
\text { LKPD. } \\
- \text { Identify and } \\
\text { assess risks in the } \\
\text { preparation of the } \\
\text { LKPD. }\end{array}$ & $\begin{array}{l}\text { - The process of preparing Local Government Work } \\
\text { Unit (SKPD) is carried out based on the Regional } \\
\text { Financial Management Procedure System, Minister } \\
\text { of Home Affairs Regulation Number } 64 \text { of } 2013 \\
\text { concerning Implementation of Accrual-Based } \\
\text { Government Accounting Standards in Local } \\
\text { Governments, SAP and Bandung District } \\
\text { Government Accounting Policies. } \\
\text { - The process of preparing SKPD is carried out using } \\
\text { the SIMDA application, and the manual is for } \\
\text { mapping accounts according to Permendagri, initial } \\
\text { balance input and adjustment / correction journals. } \\
\text { To minimize errors, currently the adjustment / } \\
\text { correction journal can only be done by the } \\
\text { Accounting Sector based on the request of } \\
\text { supporting documents from the SKPD. } \\
\text { - Risks in the preparation of the LKPD include input } \\
\text { errors in receipt, lack of and incorrect recording on } \\
\text { grant income, recording errors from administration } \\
\text { of fixed assets and inventories, and accrual journal } \\
\text { errors by recording in equity. } \\
\text { - Consolidation is carried out through the system and } \\
\text { there is reconciliation of financial reporting with } \\
\text { SKPD every quarter. }\end{array}$ \\
\hline
\end{tabular}

\section{Document Analysis}

The documents analyzed in this study include the 2018 LKPD review work program, report on the results of the 2018 LKPD review, and BPK Audit Report on Bandung District LKPD 2017 and 2018. The results of document analysis are summarized in table 2 below: 
Table 2 Document Analysis Results

\begin{tabular}{|c|c|c|}
\hline No & Document & Analysis Result \\
\hline 1 & $\begin{array}{l}2018 \text { LKPD Review } \text { Work } \\
\text { Program (PKR) }\end{array}$ & $\begin{array}{l}\text { PKR includes work review steps, review techniques, data } \\
\text { sources, implementers, and implementation times. The work } \\
\text { steps listed in the review work program in broad outline are } \\
\text { ensuring that the classification, measurement and disclosure of } \\
\text { accounts in the balance sheet, Budget Realization Report } \\
\text { (LRA), and Cash Flow Report (LAK) have been prepared in } \\
\text { accordance with SAP, while work steps specifically are search } \\
\text { towards Fixed Assets numbers. }\end{array}$ \\
\hline 2 & $\begin{array}{r}\text { Report on LKPD Review } \\
\text { Results in } 2018\end{array}$ & $\begin{array}{l}\text { The findings of the LKPD review included deficiencies in } \\
\text { accounting policies, as well as weaknesses in financial } \\
\text { management procedures. The misrepresentation of the LKPD } \\
\text { includes income from unrecorded grants, errors in measuring } \\
\text { the value of asset donations, errors in the cash balance of BOS } \\
\text { funds, Prepaid Expenses, Receivables and Fixed Assets. }\end{array}$ \\
\hline 3 & $\begin{array}{l}\text { BPK Audit Report (2017 and } \\
\text { 2018) }\end{array}$ & $\begin{array}{l}\text { The analysis of the BPK LHP is limited to the material } \\
\text { correction of misstatement in the Unaudited LKPD. Analysis } \\
\text { results show that there are material misstatements, especially in } \\
\text { the account of equity correction, tax receivables with their } \\
\text { allowances, the burden of BOS funds, inventory (especially } \\
\text { those from central grants), transfer income, grant income, and } \\
\text { fixed assets (there are double recording and capitalization } \\
\text { problems). In addition, there is a miscalculation in the } \\
\text { depreciation of fixed assets. }\end{array}$ \\
\hline
\end{tabular}

\section{Open Ended Questionnaire}

The open ended questionnaire aims to deepen the risk identification process with risk owners as respondents, which is distributed to SKPD Financial Administration Officers (PPK), Regional Property (BMD) Officers, Goods Administrator, Head of Accounting, Head of Sub Division of Accounting and Finance.

The questionnaire is divided into four parts according to the process to be identified. Respondents in each questionnaire were adjusted to the relevant fields so that the right risk identification results can be obtained. The question in the questionnaire is the result of the researchers' initial analysis of the business process of the preparation of the LKPD and the risks in each of these processes. The results of the preliminary analysis were obtained through a preliminary interview with the Head of Accounting and document analysis. Questions on the questionnaire mention the initial risks that have been identified by the researcher to be chosen by the respondent for the possibility of occurrence, as well as open questions on the questionnaire to accommodate input from respondents regarding other risks that may occur in each LKPD preparation process.

The results of risk identification in the questionnaire are explained as follows:

a. The biggest risk identified by respondents in the financial administration process was the mistake of inputting account codes or transaction values when inputting the Deposit Certificate (STS) in the SIMDA application (55.10\%).

b. The biggest risk identified by respondents in the BMD administration process is the input of Fixed Assets mutations in the SIMDA Barang application (54.55\%).

c. The biggest risk identified by respondents in the process of preparing SKPD financial statements is the error of recording fixed asset reclassification journals $(53.06 \%)$.

The biggest risk that was identified by respondents in the LKPD preparation process was the mistake of mapping the SIMDA account (100\%). 


\section{Discussion}

\subsection{LKPD Review Planning at Bandung District Inspectorate}

The results of the interview and document analysis showed that the Bandung

District Inspectorate carried out a LKPD review plan through three stages as in Figure

1.

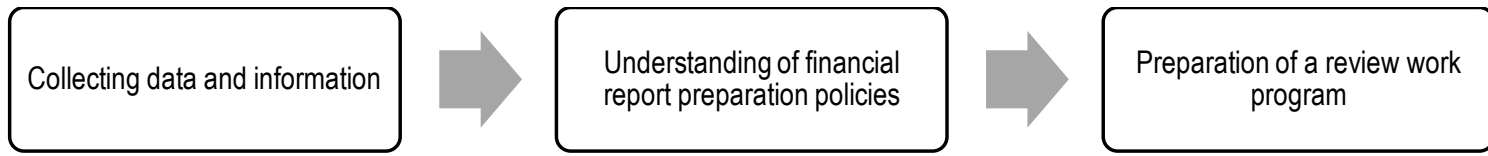

Figure 1 Planning stage of LKPD review at Inspectorate of Bandung District

The collection of data and information is carried out through the data request of financial report from $60 \mathrm{SKPD}$, and coordination with the BAKD to find out the problems on financial statements will be reviewed. An understanding of the policy of preparing financial statements is obtained through a review of the established accounting policies and procedures for regional financial management procedures. Information obtained from data collection activities and understanding of policies later became the basis for the Inspectorate in compiling a review work program.

Based on the results of interviews with the Team Leader Review and analysis of documents (work program and review report) it is known that there are differences between the procedures listed in the review work program and the implementation of the review, because there are conditions or findings in the field that require the review team to add or revise review procedures which exists. This is due to the preparation of the review program that has not applied a risk-based approach, resulting the review procedures not on target, does not lead to areas that have high risk, and not specific to detect misstatements in financial statements. In addition, the Team Leader Review stated that the absence of a Standard Operating Procedure (SOP) in planning review was one of the causes of inadequate review procedures.

Through risk-based review planning, each risk will be identified and assessed as material in the preparation of a review program so that the review will run more effectively and efficiently to achieve its objectives as proposed in this study. This is in line with the results of research on transaction cost theory which states that internal audits should be able to provide added value to the organization through cost savings, in this study the implementation of reviews can be carried out more efficiently through risk-based review planning

\subsection{Design of Accrual LKPD Review Plan with Risk-Based Approach}

The stages of review planning in this study refer to the Internal Audit Standards compiled by IIA, consisting of an understanding of the entity, identification and assessment of risks, determination of objectives and target of the assignment, and preparation of work programs. The output of this review plan is a risk-based LKPD review work program that will contain testing procedures in implementing LKPD reviews.

\section{Understanding of Entities}

The entity's understanding of the LKPD review plan aims to identify each business process in the area. Business process analysis is produced through interviews with the Head of Accounting and document analysis. In this study, the business process in the review area is that the preparation of the LKPD is explained in four stages as in Figure 2. 


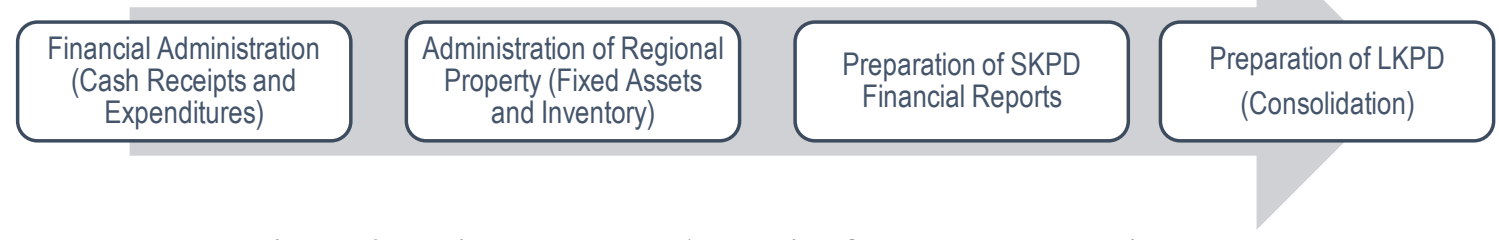

Figure 2 Business Process Analysis of LKPD Preparation

Financial administration includes the activities of the Regional General Treasurer, Treasurer of SKPD Receipts and Expenditures in the process of receiving income, expenditure, and financing. This process is carried out through the application of the Financial Management Information System (SIMDA), but there is a manual process that must be done including inputting transaction documents. The outpot of this process will result in income, expenditure, financing, and Remaining More Budget Financing (SILPA) positions in the Budget Realization Report (LRA).

Regional Property Administration (BMD) includes administration of inventory and fixed assets in the SKPD, and reporting on the BMD Sector in BAKD. Reporting in the BMD field consists of the processes carried out by SIMDA Goods application, namely the calculation of depreciation of fixed assets, as well as manual processes, namely recording inventory receipts and expenditures, fixed asset transfer inputs and mapping of fixed assets for the preparation of CaLK notes. The output of this process will produce the value of inventory, fixed assets, other assets and accumulated depreciation in the balance sheet. In addition, it will also produce the value of inventory costs and depreciation expenses in the Operational Report (LO).

Preparation of SKPD financial reports is carried out by the SIMDA Finance based on transactions that are input into the financial administration process. In addition, there is a process that is carried out manually at this stage, namely the import of the balance sheet initial balance in SIMDA, the recording of corrections and adjusting journals, and the preparation of CaLK. The output of this process is the financial statements of 60 SKPD which will be consolidated by the BAKD (Accounting Sector).

The consolidation process of SKPD financial statements is carried out by SIMDA Finance, but in this process there is a manual process that must be carried out including mapping accounts according to Permendagri Number 64 of 2013 on SIMDA, adding new account codes if any, and preparing consolidated CaLK. The output of this process is the final result that will be reviewed by the Inspectorate of Bandung District before being submitted to the Supreme Audit Agency (BPK) for an audit.

\section{Risk Identification}

As material in identifying risks in the LKPD preparation process, researchers conducted interviews with the Head of Accounting as the risk owner, as well as carried out an analysis of the BPK audit findings and the results of a review of the Inspectorate. The risk identification process was also deepened by distributing the open-ended questionnaire to the risk owners at the SKPD as respondents. The results of risk identification produce 11 risks in the financial administration process, BMD, and preparation of SKPD financial reports, as well as consolidation as illustrated in table 2.

\section{Risk Assessment}

The results of risk identification are then assessed based on the impact and possibility of occurrence based on predetermined assessment criteria, namely through benchmarking on the risk assessment criteria that have been implemented by the Ministry of Finance. This criterion is the Decree of the Minister of Finance (KMK) of the Republic of Indonesia Number 845 / KMK.01 / 2016 concerning the Implementation Guidelines for Risk Management in the Ministry of Finance.

An assessment of the impact and likelihood of risk is carried out based on the results of interviews with the Head of Accounting, and the results of document analysis, namely the LHP BPK in 2017-2018, and findings on the results of the review of the Inspectorate. 


\section{Designing a Risk-Based Review Plan for Accrual Based Local Government Financial Reports}

The results of the identification of the impact and likelihood of the risk being converted into the score, then the level of risk is measured so as to produce a risk assessment outlined in table 3 . Then a risk mapping is carried out to determine risk area using the analysis matrix as shown in figure 3 .

Table 3 Results of Risk Assessment in Bandung District LKPD

\begin{tabular}{|c|c|c|c|c|c|c|}
\hline No & Risk events & Likelihood & Impact & $\begin{array}{l}\text { Risk } \\
\text { Level }\end{array}$ & $\begin{array}{l}\text { Over Risk } \\
\text { Appetite } \\
\text { (Yes/No) }\end{array}$ & Account affected \\
\hline 1 & $\begin{array}{l}\text { The presentation of initial balance } \\
\text { value does not match with previous } \\
\text { year Audited Financial Report }\end{array}$ & 2 & 4 & 14 & Yes & All accounts \\
\hline 2 & $\begin{array}{l}\text { Error recognizing adjustment / } \\
\text { correction journal. }\end{array}$ & 5 & 4 & 23 & Yes & All accounts \\
\hline 3 & $\begin{array}{l}\text { Unrecorded accrual expense / } \\
\text { income. (recorded in equity) }\end{array}$ & 4 & 4 & 19 & Yes & All accounts \\
\hline 4 & $\begin{array}{l}\text { Notes of Financial Statements do not } \\
\text { provide sufficient information. }\end{array}$ & 2 & 2 & 7 & No & All accounts \\
\hline 5 & $\begin{array}{l}\text { Addition of inventory from a central } \\
\text { grant has not been recorded. }\end{array}$ & 4 & 3 & 16 & Yes & Inventory \\
\hline 6 & Error recording inventory costs. & 4 & 3 & 16 & Yes & $\begin{array}{l}\text { Inventory, } \\
\text { Inventory Cost }\end{array}$ \\
\hline 7 & $\begin{array}{l}\text { Error inputting fixed assets mutation } \\
\text { in SIMDA application }\end{array}$ & 3 & 2 & 10 & No & Fixed Asset \\
\hline 8 & $\begin{array}{l}\text { Problems with maintenance spending } \\
\text { have an effect on the capitalization } \\
\text { and economic life of fixed assets }\end{array}$ & 4 & 4 & 19 & Yes & Fixed Asset \\
\hline 9 & $\begin{array}{l}\text { Error recording the reclassification } \\
\text { of fixed assets. }\end{array}$ & 3 & 2 & 10 & No & Fixed Asset \\
\hline 10 & $\begin{array}{l}\text { Error inputting the account code / } \\
\text { transaction value when entry Deposit } \\
\text { Letter (STS) in the SIMDA } \\
\text { application. }\end{array}$ & 3 & 2 & 10 & No & $\begin{array}{l}\text { Income, Other } \\
\text { Income }\end{array}$ \\
\hline 11 & $\begin{array}{l}\text { Error mapping the account on } \\
\text { SIMDA }\end{array}$ & 3 & 2 & 10 & No & All accounts \\
\hline
\end{tabular}

\begin{tabular}{|c|c|c|c|c|c|c|c|}
\hline \multirow{3}{*}{\multicolumn{3}{|c|}{ Risk Analysis Matrix }} & \multicolumn{5}{|c|}{ Impact Level } \\
\hline & & & \multirow{2}{*}{$\frac{1}{\text { Not }}$} & \multirow{2}{*}{$\frac{2}{\text { Minor }}$} & \multirow{2}{*}{$\frac{3}{\text { Moderat }}$} & \multirow{2}{*}{$\frac{4}{\text { Significantly }}$} & \multirow{2}{*}{$\begin{array}{c}5 \\
\text { Very } \\
\text { Significant }\end{array}$} \\
\hline & & & & & & & \\
\hline \multirow{5}{*}{$\begin{array}{r}\text { Likelihood } \\
\text { Level }\end{array}$} & & $\begin{array}{l}\text { Almost } \\
\text { certainly occur }\end{array}$ & & & & 2 & \multirow{4}{*}{ 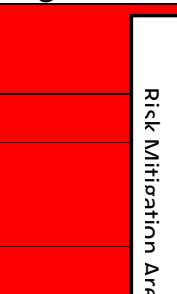 } \\
\hline & 4 & Often occur & & & 5,6 & 3,8 & \\
\hline & 3 & $\begin{array}{l}\text { Sometimes } \\
\text { occur }\end{array}$ & & $\begin{array}{c}7 \\
9,10,11\end{array}$ & & & \\
\hline & 2 & Rarely occur & & 4 & & 1 & \\
\hline & & $\begin{array}{l}\text { Almost never } \\
\text { occur }\end{array}$ & & & & & \\
\hline
\end{tabular}

Figure 3 Risk Analysis Matrix of Bandung District LKPD 
Based on the results of the risk assessment, it is known that five risks are in the risk acceptance area, and 6 risks are above the risk acceptance area. Risks that are in the area of risk mitigation and will be followed up consist of one risk with very high value, four risks with high value, and one risk with moderate value. The risk is then followed up with the preparation of procedures in the review work program. The results of the risk assessment at this stage will be a reference in determining the next steps, especially at the procedure preparation stage in the review work program.

\section{Setting Goals and Objectives of the Review}

The purpose of the LKPD review refers to Permendagri No.4 of 2008 concerning Implementation Guidelines for Review of LKPD, namely to provide limited confidence that the LKPD is prepared based on an adequate internal control system and is presented in accordance with government accounting standards.

Based on the assignment objectives and the results of the risk analysis, the assignment objectives proposed in this study focus on areas that have moderate, high and very high risks. Based on these areas, the objectives of the Bandung District LKPD review are on inventory accounts and inventory expenses, fixed assets, and adjustment or correction journals that affect the equity account.

\section{Compilation of Review Work Programs}

Based on the six risks considered to be above the risk acceptance area, researchers designed testing procedures that could be applied to Inspektora Bandung district in the implementation of the LKPD review. The review program contains testing steps that can be done by the Bandung District LKPD review team to detect misstatements in financial statements, presented in Appendix 1.

\section{Conclusion}

\subsection{Research conclusion}

Planning is an important stage in the review assignment, especially in determining the testing procedures to be carried out so that there is a limited belief that the financial statements have been presented in accordance with applicable accounting standards. The implementation of the LKPD review plan at the District Inspectorate was carried out according to IIA provisions and standards, but there were weaknesses that could lead to a less effective review including the Inspectorate had not yet understood the application system and business processes in the area reviewed, risk identification was not structured and documented in a working paper, so the results are not followed up with risk assessment and are not used as material for preparing a review program. In addition, it was also known that the testing procedures compiled in the review program did not meet the needs of the team in conducting the review so that there were discrepancies between the procedures and the implementation of the review in the field. The main cause of the whole problem is that the risk-based approach has not been applied in planning the review so that this research will propose this.

The draft planning review is carried out in several stages. The first stage of the planning review results in an analysis of business processes in the preparation of the LKPD so that weaknesses can be identified in each process which creates a risk of misstatement. In the second stage the researcher identified risks based on weaknesses in the process of preparing the LKPD which produced a list of initial risks. The list of initial risks is then re-analyzed through interviews and questionnaires with risk owners to produce a risk register consisting of 11 risks. The third stage in this study produced a risk analysis matrix. The matrix is generated through a risk assessment process by considering the impact and likelihood of risk using predetermined criteria, resulting in six risks that need to be followed up because they are above the risk acceptance area.

Based on the results of the risk assessment it was concluded that the presentation errors in the Bandung District LKPD were caused by errors in the adjusting journal by recording in the equity account so that there was a material misstatement on accrual income and expenses in the Operational Report. This is due to the lack of understanding of the financial report compiler to accrual-based SAP. In addition, there are also many 
misstatements in inventory accounts, fixed assets, and grant income. All of these risks need to be mitigated with adequate review testing procedures so that the LKPD can be presented in accordance with SAP. The final stage in this study is to follow up on six risks that need to be mitigated by preparing testing procedures so that a risk-based LKPD review program can be produced that can be applied to the Bandung District Inspectorate.

\subsection{Research limitations}

The RBIA approach applied in this study aims to design a risk-based review program, and cannot be the basis for preparing a risk management framework for the Bandung District Government. Suggestions for subsequent research can be carried out by linking the context of risk management comprehensively to the entities that become object of research.

\section{References}

Alhakim, A. (2015). Analisis atas Reviu Laporan Keuangan Pemerintah Daerah oleh Aparat Pengawasan Intern Pemerintah (APIP) pada Pemerintah Provinsi DKI Jakarta. Universitas Indonesia.

Ayagre, P. (2014). The Adoption of Risk Based Internal Auditing in Developing Countries: the Case of Ghanaian Companies. European Journals of Accounting Auditing and Finance Research, 2(7), 52-65.

Bekaiang, A. F., Sondakh, J. J., \& Kalalo, M. Y. B. (2017). Pengaruh Prosedur Reviu Terhadap Kualitas Reviu Laporan Keuangan Pemerintah Daerah Di Kabupaten Minahasa Utara. Jurnal Riset Akuntansi Going Concern, 3(1), 1177-1204.

Coetzee, P., \& Lubbe, D. (2014). Improving the efficiency and effectiveness of riskbased internal audit engagements. International Journal of Auditing, 18(2), 115125. https://doi.org/10.1111/ijau.12016

COSO. (2004). Enterprise Risk Management-Executive Summary. Jersey City.

Creswell, J. W. (2014). Research Design- Qualitative, Quantitative, and Mixed Methods Approaches. London: SAGE Publications.

Efendi, R., Dewi, F. G., \& Gamayuni, R. R. (2018). Usefulness Analysis Of Accrual Based Accounting Information On Local Government Financial Statement: A Qualitative Study. International Journal of Scientific \& Technology Research, 7(11), 10-21.

Fraser, S. (2011). The Risk-Based Audit approach. Accounting, Tax \& Banking Collection Pg. 54 Reproduced.

IAASB. (2016). Handbook of International Quality Control, Auditing, Review, Other Assurance, and Related Services Pronouncements. New York: IFAC.

IIA, T. I. of I. A. (2014). Risk Based Internal Auditing. Retrieved from https://global.theiia.org/standardsguidance/topics/Documents/201501GuidetoRBIA.pdf

IIA, T. I. of I. A. (2016). All in a Day 's Work. https://doi.org/10.5465/AMR.2000.3363315

IIA, T. I. of I. A. (2017). International Standards for the Professional Practice of Internal Auditing (Standards).

International Federation of Accountants. (2011). Transition to the Accrual Basis of Accounting: Guidance for Governments and Government Entities. 
Maulana; Djamhuri; Purwanti. (2017). Determinan Kualitas Reviu Dan Implikasinya Terhadap Kualitas Laporan Keuangan Pemerintah Daerah. Jurnal Economia, 13(2), 118-127. https://doi.org/10.21831/economia.v13i2.14980

Pickett, K. H. S. (2010). The Internal Auditing Handbook. Chichester: Willey.

Moeller, R. R. (2009). Brink's Modern Internal Auditing Eighth Edition (8th ed.). New Jersey: Wiley.

Moeller, R. R. (2011). COSO ERM. New Jersey: Wiley.

Sarens, G., Abdolmohammadi, M. J., \& Lenz, R. (2012). Factors associated with the internal audit function's role in corporate governance. Journal of Applied Accounting Research, 13(2), 191-204. https://doi.org/10.1108/09675421211254876

Spraakman, G. (1997). Transaction cost economics: a theory for internal audit? Managerial Auditing Journal, 12(7), 323-330. https://doi.org/10.1108/02686909710180670

Sumanjaya. (2015). Optimalisasi penyelenggaraan reviu atas pelaporan keuangan pemerintah daerah: studi kasus pada Inspektorat Provinsi kepulauan bangka Belitung. Universitas Indonesia.

Widyarini, K., Made, N., \& Ratnadi, D. (2016). Pengaruh Prosedur, Pendidikan, Tekanan Waktu, Dan Anggaran Reviu Pada Kualitas Reviu Laporan Keuangan Pemerintah Daerah. Jurnal Ekonomi Dan Bisnis Universitas Udayana, 455-488.

Williamson. (1985). The Economic Institutions of Capitalism. New York: The Free Press.

Yin, R. K. (2003). Applications of Case Study Research. Interpretive Interactionism (Second Edi). London: SAGE Publications. 


\section{Appendix 1}

\section{Design Procedure Testing Review of Bandung District LKPD}

\begin{tabular}{|c|c|c|c|}
\hline No & Risk & Affected Account & Procedure Review \\
\hline 1 & $\begin{array}{l}\text { The presentation of the } \\
\text { value of the initial } \\
\text { balance does not match } \\
\text { the Audited Financial } \\
\text { Report of the previous } \\
\text { year. }\end{array}$ & $\begin{array}{l}\text { Accumulated } \\
\text { Depreciation account } \\
\text { (Based on previous audit } \\
\text { findings) }\end{array}$ & $\begin{array}{l}\text { 1. Browse the value of the initial balance of each balance sheet, especially in the Accumulated } \\
\text { Depreciation account. } \\
\text { 2. Compare the value of the initial balance with the previous year's audited BPK, if there are } \\
\text { differences discussing with the related fields. } \\
\text { 3. If there is a difference in the initial balance in the Accumulated Depreciation account, do a } \\
\text { search of the details of the asset, then compare whether there is a reclassification / deletion of } \\
\text { the asset. }\end{array}$ \\
\hline 2 & $\begin{array}{l}\text { Error acknowledging } \\
\text { adjustment / correction } \\
\text { journal. }\end{array}$ & $\begin{array}{l}\text { Equity account } \\
\text { (Based on previous audit } \\
\text { findings) }\end{array}$ & $\begin{array}{l}\text { 1. Identify mutations in equity values in the Changes in Equity Report, specifically those } \\
\text { recorded in the equity correction. } \\
\text { 2. Perform an analysis of the correctness of the equity correction journal, ask for detailed } \\
\text { journals and supporting documents, if necessary browse to the ledger. } \\
\text { 3. Analysis of whether the journal on equity correction is the current year transaction that } \\
\text { should be recorded in the expense / income in the Operational Report. } \\
\text { 3. If there is a journaling error, confirm to the party who conducted the journal and discuss the } \\
\text { proposed correction journal. }\end{array}$ \\
\hline
\end{tabular}




\begin{tabular}{|c|c|c|c|}
\hline No & Risk & Affected Account & Procedure Review \\
\hline 3 & $\begin{array}{l}\text { There is an unrecorded } \\
\text { accrual expense / } \\
\text { income. (recorded in } \\
\text { equity correction) }\end{array}$ & $\begin{array}{l}\text { Grant income accounts, } \\
\text { tax and transfer income } \\
\text { (Based on previous audit } \\
\text { findings) }\end{array}$ & $\begin{array}{l}\text { Grant Income: } \\
\text { 1. Collect data of grant / CSR receipts for each SKPD, then explore whether it has been } \\
\text { recorded on grant income in the LO. If recorded on another account, discuss the correction } \\
\text { journal. } \\
\text { Prepaid income: } \\
\text { 1. Identify the realization of income paid for more than } 1 \text { year (for example: advertisement } \\
\text { tax, land rent). } \\
\text { 2. Analysis of whether the recognition of income received in advance has been correct / in } \\
\text { accordance with the contract, and income for the current year has been recorded in the LO. } \\
\text { Transfer Income: } \\
\text { 1. Test whether the transfer funds received are in accordance with the provisions / decrees } \\
\text { from the center. } \\
\text { 2. Identification if there is income that has been determined in the decree but has not been } \\
\text { received (example: Provincial Revenue Sharing Funds). Make a record of income in the LO. }\end{array}$ \\
\hline 4 & $\begin{array}{l}\text { The addition of } \\
\text { inventory from the grant } \\
\text { has not been recorded. }\end{array}$ & Inventory & $\begin{array}{l}\text { 1. Identify grants from the center in the form of inventory items at each SKPD. } \\
\text { 2. Perform a search on whether the inventory originating from the grant has been recorded on } \\
\text { the balance sheet, and becomes a burden on the LO if it has been used. }\end{array}$ \\
\hline 5 & $\begin{array}{l}\text { Error recording } \\
\text { inventory burden. }\end{array}$ & Inventory Burden & $\begin{array}{l}\text { 1. Analysis of details of Service Expenses. Identification if there is an inventory expense } \\
\text { recorded on service expenses. } \\
\text { 2. Analysis of details of inventory expenses. Identify if there are inventories submitted to third } \\
\text { parties and should be classified into Grant Charges. }\end{array}$ \\
\hline
\end{tabular}




\begin{tabular}{|c|c|c|c|}
\hline No & Risk & Affected Account & Procedure Review \\
\hline 6 & $\begin{array}{l}\text { Problems with } \\
\text { maintenance spending } \\
\text { have an effect on the } \\
\text { capitalization and } \\
\text { economic life of fixed } \\
\text { assets }\end{array}$ & Fixed Asset & $\begin{array}{l}\text { 1. Identify maintenance expenditures that can be capitalized according to accounting policies. } \\
\text { 2. Browse whether all maintenance expenditures that meet the requirements have been } \\
\text { capitalized on asset values. } \\
\text { 3. Browse if there is a record of expenses that should be capitalized, and do a correction } \\
\text { journal. } \\
\text { 4. Browse whether capitalization has added useful life, analyze whether the additions are in } \\
\text { accordance with accounting policies, and analyze their effects on depreciation values. } \\
\text { 5. Browse capitalized shopping attribution (eg maintenance spending, planning). Has the } \\
\text { attribution been attached to the Fixed Assets related or is still independent. }\end{array}$ \\
\hline
\end{tabular}

